This item was submitted to Loughborough's Research Repository by the author.

Items in Figshare are protected by copyright, with all rights reserved, unless otherwise indicated.

\title{
Exploring the delivery of officer safety training: a case study
}

PLEASE CITE THE PUBLISHED VERSION

https://doi.org/10.1093/police/pax095

PUBLISHER

Oxford University Press $@$ The Author

\section{VERSION}

AM (Accepted Manuscript)

\section{PUBLISHER STATEMENT}

This is a pre-copyedited, author-produced version of an article accepted for publication in Policing: A Journal of Policy and Practice following peer review. The version of record CUSHION, C.J., 2018. Exploring the delivery of officer safety training: a case study. Policing: A Journal of Policy and Practice, 14(1), pp. 166-180 is available online at: https://academic.oup.com/policing/advance-article/doi/10.1093/police/pax095/4803079 and https://doi.org/10.1093/police/pax095.

\section{LICENCE}

CC BY-NC-ND 4.0

\section{REPOSITORY RECORD}

Cushion, Christopher. 2018. "Exploring the Delivery of Officer Safety Training: A Case Study". Loughborough University. https://hdl.handle.net/2134/32981. 
7

8

9

10

11

12

13

14

15

16

17

18 


\section{Introduction}

2

"When...the police officer is rolling around the floor of a public house in mud, blood and beer, their inability to cope with violent encounters becomes apparent"' (Buttle, 2007, p. 165).

Of any occupation, the police are most exposed to violence (Waddington, Badger, \& Bull, 2006) with data from England and Wales alone suggesting 23,000 reported assaults on police officers in 2015/16 (Home Office, 2017). Police safety and use of force decisions are an ongoing source of concern for both the police and the public (Andersen \& Gustafsberg, 2016) but research investigating police violence and use of force remains limited (Buttle, 2007). Indeed, relatively little is known, in comparison to other factors, about police officers' ability to adequately manage violence or factors that influence this ability (Renden, Nieuwenhuys, Savelsbergh, \& Oudejans, 2015a; Renden, Landman, Savelsbergh, \& Oudejans, 2015b). Volatile and violent encounters present "complex, multi-faceted and sometimes subtle problems" (Waddington, et al., p.182), but in preparation for violent situations, police officers are trained in a "largely off the shelf" and "rather stereotyped catalogue" (Waddington et al., 2006, p.181) of arrest and self-defence skills (ASDS) - known in the UK as officer safety training (OST). Surprisingly, few studies are concerned specifically with OST and training around use of force (Andersen \& Gustafsberg, 2016; Buttle, 2007) and this research looks to address this gap by generating empirical evidence about OST, its content and delivery. from officers, rather than a rational analysis of training needs "a case of the blind leading the blind" (Buttle, 2007, p.177) - with little evidence supporting the efficacy of prescribed training regimes (Waddington et al., 2006). Indeed, experiences of officers suggests that they struggled 
1 to apply taught arrest and self-defence techniques (e.g. Jager, Klatt, \& Bliesner, 2013; Renden,

2 et al., 2015a) yet paradoxically, officers competent in use of force have a wider range of

3 techniques and use less force than unskilled and often frightened officers who are more likely

4 to use excessive force (e.g. Andersen \& Gustafsberg, 2016; Geller \& Toch, 1996; Buttle, 2007).

5 The underlying presumption of OST is that its content and delivery provides all police officers

6 with sufficient experience of conflict and the use of force. In addition, hard-pressed officers

7 and trainers, with insufficient time to reflect deeply on the content and delivery of training, are

8 likely to end up simply reproducing it (Karp \& Stenmark, 2011), and in these terms, develop

9 and legitimise practice for compliance purposes (Beighton \& Poma, 2015), that is to 'get

10 officers through' the requisite training rather than be concerned with training effectiveness.

11 Therefore, there remains a need for empirical research into police training is a means to

12 establish 'what works' in a professionalised police force, using the best available evidence;

13 what the College of Policing in the UK describe as 'evidence based policing' (College of

14 Policing, 2017; Beighton \& Poma, 2015). However, there is limited empirical evidence that

15 examines directly police use of force training (Morrison \& Garner, 2011; Staller \& Zaiser,

16 2015) and with little or no evidence base OST remains entirely unproven (Buttle, 2007;

17 Waddington et al., 2006) in terms of the outcomes it produces.

The amount of time and financial resources for police training are limited and OST is

19 time compressed training (refreshed annually over two days, with the time spent on ASDS only

20 between 8 and 12 hours per year (Timmer \& Pronk, 2011)). Time spent on task is a key variable

21 in 'deliberate practice' (Ericsson, 2014) and is related to instructional design skills, and the

22 skill of the instructor/trainer. Hence training needs to maximise engaged activity. The time

23 spent by officers appropriately/successfully engaged in subject matter-related tasks and having

24 an 'opportunity to learn' links with officer achievement and is a process indicator of learning 
1 (van der Mars, 2006). Importantly, Berliner (1979) argued that teachers (sic instructors) can

2 influence achievement directly by arranging their instruction in ways that maximise the time

3 the learner spends in direct and successful contact with learning tasks. Activity alone is not

4 sufficient, as learners need to have task engagement, and if the task is too easy or too difficult

5 engagement will not be sufficient for learning.

Further, in addition to the skills of the trainer and 'time on task', there is a consensus

7 in the police and military literature that the type of practice activities is key, with repeated

8 experiential based practice linked to performing more effectively in situations that requires use

9 of force (e.g. Broome, 2011; Dror, 2007; Miller, 2007; Murray, 2004; Staller \& Zaiser, 2015

10 inter-alia). Importantly, Renden et al. (2015a) stated "how individuals train is crucial in skill

11 acquisition” (p.16), hence considering 'what to teach' (which techniques or what 'system')

12 needs to be balanced with a consideration of 'how to teach' (instructor methodology) to ensure

13 officers can apply techniques learned in training in real life situations. Such an approach

14 pushes more responsibility to the trainer who is responsible for considering and deciding about

15 all aspects of the training session (Morrison \& Garner, 2011; Staller \& Zeiser, 2015) thus

16 making trainer practice worthy of investigation.

Recent work by Renden and colleagues (2015) indicated that police officers wished for more 'realistic' training delivered in a way that is "more comparable to the high-pressure situations that officers face in the line of duty" (Renden et al., 2015a, p. 17). Officers describe a difference between their training experiences and incidences of violence which involved

21 increased pressure, (physical, cognitive and emotional) (Staller \& Zaiser, 2015) and that 22 occurred in chaotic circumstances (Jager et al., 2013) resulting in perceptual deterioration associated with high stress arousal (Andersen \& Gustafsberg, 2016). Training programmes 
1 depend on the transfer of skills learned in the training environment to real world contexts or

2 the 'criterion environment'. Hence the more representative or 'real' the learning environment,

3 the better the transfer of skills from that environment to performance situations (Broadbent,

4 Causer, Williams \& Ford, 2015). Indeed, Wheller et al. (2013) Wheller and Morris (2010), and

$5 \quad$ Miller and Alexandrou (2016) identified that 'modelling behaviours' through scenario training

6 is more likely to impact 'street-level' officer behavior and can improve 'traditional' delivery

7 of police training beyond "talking heads" to interactive adult education (Rosenbaum \&

8 Lawrence, 2017, p. 319). Currently however, training practices may not simulate the conditions

9 an officer experiences in real-world encounters (Andersen, Pitel, Weerasinghe, Papazoglou,

10 2016; Waddington et al., 2006). Importantly, from a learning perspective, it is not just the

11 learner's perception of the 'reality' of the training, instead, the "functional alignment with the

12 learning task, the instructional design, and the instructor will have far greater impact in

13 immediate learning, retention and transfer to new settings" (Hamstra et al., 2014, p. 389).

Existing research shows that there remains an important relationship between training room processes and learner achievement; time and activity are tangible and observable process indicators of learning (in OST the skills are movement based and directly observable) -

17 appropriate and successful task engagement (expressed in time or frequency) are widely 18 accepted as 'proxy' indicators for learning (Siedentop, 2002a; van der Mars, 2006). Hence, 19 the quality of instruction combined with the type of practice activity undertaken makes a 20 difference to learning achievement and course delivery effectiveness. The purpose of this 21 research therefore, was to provide empirical evidence concerning the structure, organisation, 22 content, and delivery of OST and consider how it is configured to provide adequate time and 23 regularity of practice to deliver its outcomes. The significance of this work lies in providing 24 evidence of current practice and in advancing understanding OST to open discussion about 
1 ways for improving police OST. Until research is conducted on OST that considers its content

2 and delivery specifically, any arguments about its effectiveness or otherwise remain 3 speculative, and training will continue to be organised and conducted without the benefit of 4 objective and empirically based evidence.

\section{Methodology}

7 As the research was bounded by a specific time frame, and by a particular case, data were 8 collected using a case study methodology. Berg (2007) defines a case study as "a method 9 involving systematically gathering enough information about a person, social setting, event, or 10 group to permit the researcher to effectively understand how the subject operates or functions" 11 (p. 283). The purpose of the case study reported here was to gather "rich, detailed and in-depth 12 information" (p.283) on a single phenomena and "uncover the manifest interaction of 13 significant factors characteristic of this" (p. 284). Hence case studies are an appropriate 14 methodological approach when the purpose of the study is to understand the 'case', in depth. 15 Moreover, and according to Yin (2013) case study is the most appropriate research design to 16 adopt when examining a phenomenon that has previously not been explored. Importantly, the 17 value of case studies to generate context dependent knowledge, with the aim that readers might 18 elicit case knowledge that offers authenticity and transferability (Grunbaum, 2007) and 19 recognise where the 'case' aligns with their own biographies and experiences.

This case study was conducted with frontline police officers in a large county

21 constabulary. The case was descriptive and illustrative generating local knowledge about OST.

22 The courses provided the analytical frame with the object being the process and experience of 23 the training (Thomas, 2011). Access was gained to three annual officer-safety training courses. 
1 All UK police officers are required to attend OST annually - the courses are 'attend only', and

2 the only assessment is a pass or fail fitness assessment at the beginning of the course. The

3 trainers have a substantial 'manual' to guide the training that contains 'approved' techniques -

4 the trainers however have considerable latitude to draw from this manual to devise the courses.

5 The courses ran over two days from $8.30 \mathrm{am}$ to approximately $4.30 \mathrm{pm}$ each day. During the

6 two days all aspects of officer safety training were covered (first aid, self-defence, control and

7 restraint, cell clearance, and scenario training including first aid and law based issues) - though

8 the order of delivery varied for each course.

9

Methods

10

11 Participant observation is "an omnibus field strategy" (Patton, 1990, p.206) in that it

12 "simultaneously combines interviewing of respondents and informants, direct participation 13 observation and introspection" (Denzin, 1978b, p.183). The extent of participation is a 14 continuum that varies from complete immersion as a full participant to complete separation 15 from the setting as a spectator (Patton, 1990). There is a great deal of variation along the 16 continuum between these two extremes and the extent of participation can change over time.

17 In the present study, the researcher took part in the first course as a full participant, to experience the training from a learner's perspective. In course two and three the researcher only participated in some aspects of the training. For example, taking part in demonstrations or acting as 'subject' in scenarios, but was for the majority of the time observing behaviour an observer participant. Extensive field notes were taken in addition to a 'time-on-task' analysis. The fact that the courses were being observed was made apparent to the participant officers and this allowed for informal conversations and interviews about the course and officer 
1 safety training in general during the respective courses. In total, 59 officers attended the three

2 courses where each course was staffed by two trainers. Two of the trainers delivered twice,

3 though partnered with a different instructor each time, and hence were observed on two courses

4 (five of the eight full-time trainers were observed including the 'lead trainer'). The ratio of staff

5 to officers varied over the three courses from $2: 12$ to $2: 28$.

$6 \quad$ Time on Task

7 The timing content and duration of each element of the course was noted to produce an 8 overview of each course's 'micro-structure', that is the moment-to-moment nature of the

9 course. Specific attention was paid to what individual officers were doing (activity types) and 10 with whom (individual, pairs, groups) and what trainers were doing (e.g. giving 11 instruction/feedback, demonstrating/modelling). This enabled the type and duration of learning 12 activities to be recorded, as well as giving an insight of the pedagogy employed by the instructors.

15 The data analysis was grounded both conceptually in the ideas and objectives informing the 16 research. That is, understanding training room processes and learner achievement, as well as 17 the structure, organisation, content, and delivery of OST. As well as empirically in observations 18 about relationships in the data. Specifically, the analytic process involved two phases. First, a 19 data-driven inductive thematic approach was employed (Braun \& Clarke, 2006). The data were 20 subject to two main operations: (1) breaking down raw data into meaningful 'meaning' units, 21 such as discrete phrases, sentences or series of sentences that conveyed one idea or one related 22 set of observations and (2) grouping units with similar meanings into broader categories. This 
1 involved a detailed line-by-line examination of all field notes as well as data concerning the

2 course timings and structure. Second, similar features between meaning units were identified,

3 meaning units were grouped together to organise common meaning units into distinct sub-

4 categories. Sub-categories were named according to the common features that all its meaning

5 units shared. As the data analyses proceeded, a further level of interpretation compared sub-

6 categories to organise them into larger and more inclusive themes. These themes were

7 identified in relation to the aims and purpose of the study and responses presented. For the time

8 on task observations and data this resulted in seven themes that reflected the learning activities

9 undertaken on the course. While for the fieldwork data this resulted in three themes; time on

10 task/practice activities, curriculum content and delivery, gender issues.

\section{Results}

12 Insert table 1 here

13 As can be seen from table 1 the largest percentage of time on all the courses (on average 54\%)

14 was spent watching demonstrations, receiving briefings for tasks and getting feedback on 15 previous practice. These activities were done to the entire group and were always instructor led 16 with the officers as passive receivers. The most common type of practice was working in pairs 17 (on average 28\%), though on course one this was shared with group practices.

\section{Analysis and Discussion}

\section{Time on Task/Practice Activities}

20 Across all three courses, police officers spent most time passive, standing and listening to

21 briefings, getting feedback on tasks, or watching an instructor demonstration of techniques -

22 in course 3 this was two thirds of the training time, but on average was half the time. Training 
1 methods were exclusively didactic (c.f. Beighton \& Poma, 2015) across the three courses, with

2 perfunctory attempts to engage officers with questions or discussion. The instruction, feedback

3 and demonstrations delivered were always directed to the entire group who would typically

4 stand and observe. In addition, individual feedback was scarce despite a range of abilities,

5 experience and competence with the various techniques - and despite the variability in officers'

6 practice attempts offering numerous 'teachable' moments. The following example illustrates

7 something of the considerable variability in officers' ability and the lack of differentiation in

8 the training to allow more practice for those that needed it.

9 I'm paired with an officer to practice a 'transport wrist lock', this is reasonably fiddly, 10 involving a twisting of the palm to the sky, then rotating the hand between the body and 11 the elbow into the lock. Fortunately, I recognise it as a lock from jujitsu, so I have a 12 couple of successful attempts and we switch. My partner can't do the lock he fiddles a 13 couple of attempts but can't put me in the lock. There is an uncomfortable pause while 14 we look at each other. I have to show him how to put the lock on in the absence of any 15 other help. He just about masters the basic mechanics of the lock but time is called on 16 the practice and we are called in and briefed as a group on the next technique. (Field 17 notes)

18 In the following excerpt a 'teachable' moment is missed, and the data illustrates something 19 of the of gender differences (around 'strength') apparent on the courses (see also section 20 below 'Gender Issues').

21 A female officer has a male colleague face down on the mat and is pinning them down, 22 trying to manoeuvre their right arm to the ten to two position and keep it straight. This 23 means pressure can be placed on the shoulder joint and the subject 'pinned' while the 
arm is positioned so a handcuff can be applied. The male subject is resisting this, and is a lot stronger. If he is able to bend at the elbow and place his palm on the mat he can 'push up' and the control will be lost. However, no instruction or guidance is given and the female officer is left in a battle of strength and while she holds on or as long as possible, not giving in, the subject eventually, and inevitably wins the battle. (Field notes)

6 Werth (2011) describes police training methods as traditionally instructor-centric and based in

7 behavioural education ideology. In the present study, this was the case where training was 8 based on a 'non-cognitive' behavioural paradigm with instructors, as evidenced by the time9 on-task data, talking most of the time in order to share accumulated wisdom, demonstrating simple or part drills (often without repetition), and giving some corrective information in debriefs. The expectation being that officers would passively absorb said wisdom then imitate

12 the instructor.

Such an approach may result in improvement in some performance in the immediate and short term (Soderstrom \& Bjork, 2015) - and is hence appealing to instructors as rewards can seem to be gained immediately, and reinforces a perception of a 'correct' teaching approach - but in the long-term performance will decrease particularly when encountering difficult and stressful conditions i.e. learning has not taken place (Soderstrom \& Bjork, 2015). This argument is supported by evidence that suggests that under threatening conditions police officer's performance of ASDS decreases as the training undertaken is insufficient to inhibit stimulus-driven reactions (fear of getting hit) and avoidance behaviours (Renden, et al., 2014)

\section{Curriculum content and delivery}

22 While the course time on task data shows a 'pattern' of delivery, each course had considerable 
1 instances of content variability. For example, 'control of the subject on the ground' was

2 practiced for thirty minutes on course one, and included movement and resistance from the

3 subject, it was not covered at all on courses two and three. This was connected to what appeared

4 as a lack of a shared training strategy. While all of the trainers observed were both enthusiastic

5 in their approach and knowledgeable and skilful practitioners in their own right, there did not

6 appear to be a shared training strategy for the courses or between instructors, meaning that the

7 experiences of officers on the course would vary according to which course they attended and

8 which instructor was present.

9 In the training office prior to the start of the course - the two instructors are drinking tea 10 and discussing what each will cover and who will lead which aspect. There appears to be 11 core elements to be covered but these seem 'up for grabs' between the two of them, and 12 the order of the morning changes several times before agreement is reached. (Field notes)

13 Part of this apparent lack of training strategy was also illustrated through a disconnect between

14 different sections of the course. The curriculum was delivered in blocks where it seemed the 15 content went from topic to topic, self-defence to hand cuffing to use of baton and so on, without 16 the previous topic informing or being integrated with the next.

17 It's not clear how the training goes from a self-defence scenario to a control and restraint 18 or take down scenario, these are presented and structured as discrete elements and in 19 different parts of the course, sometimes on different days - in a different part of the 20 course we're controlling subjects already under control who are passive and do not resist, 21 and cuffing on the floor subjects who have conveniently already laid down, or who are 22 entirely compliant. (Field notes) 
1 It also appeared from the three courses that methods were selected and taught in a piecemeal

2 and disjointed fashion. The trainer's limited discussions regarding the planning and delivery of

3 the courses and the delivery itself, not unlike practices reported by Kaminski and Martin

4 (2000), did not explicitly consider any criteria of delivery effectiveness (e.g. consideration of

5 structure of practice to ensure the training and maintaining of skills) or outcomes (e.g.

6 developing competent officers) - suggesting that training was in a self-confirming 'loop'; a

7 cycle which meant that it has failed to keep up with developments in the field. The piecemeal

8 nature of training was also highlighted with officers being taught using a range of methods

9 from different ASDS 'systems' with some instructors having a proprietary interest in their use

10 (cf. Kaminski \& Martin, 2000).

11 "We're looking at multiple attacker, that's come from (instructor) the techniques are

12 based on (system) and (instructor) does a lot of that training - so it's good to have

13 different things, different input - we're looking to get that 'approved' and put into the

14 manual.” (Instructor)

15 “(Instructor) came over from (force), he's an instructor and also trains and competes in 16 (system). He showed us some techniques that they're using with (force) training. It was 17 good stuff, he's trying to get that official, we're using it here as an option.” (Instructor)

18 However, the training discourse was not about effectiveness or skill development, but instead 19 was about time pressures and getting officers through the course uninjured rather than about 20 developing highly skilled practitioners.

21 "We'd like to do a bit more with them, make it a little more realistic, but then you get 22 injuries, or a perception that it will cause injuries, and complaints about the training being 23 too hard." (Field notes, Instructor) 
1 “There are too many stops and breaks that seem related to 'health and safety', it doesn't

2 produce better or realistic training, which we need. In reality, some staff are just not fit

3 enough, and the organisation doesn't seem to challenge this and seem more concerned

$4 \quad$ about injuries." (Field notes, Officer)

5 The instructor calls time on the practice. An officer remarks to no-one in particular, "is

6 that it, are we done?" Another officer walking past him "yep, that's it done for another

7 year". "That's a relief, box ticked and in one piece" (Field notes)

8 Narrow views of training risk in fact reinforce operational incompetence if they exclude

9 practices that encourage the development and application of more complex skills (Beighton \&

10 Poma, 2015) and hence this overly cautious approach could have the effect of deskilling

11 officers rather than producing officers highly skilled in ASDS.

13 In and of themselves, the self-defence and control and restraint techniques seemed 14 appropriate and adequate. However, all of the OST observed lacked realism and instead took 15 place under isolated and low-pressure conditions, were conducted under predictable 16 circumstances and were linear, both literally (in a straight line) and contextually (situation a 17 moved to $\mathrm{b}$ moved to $\mathrm{c})$. This limited realism to practice meant that techniques were not connected or transferred across the scenarios trained - thus missing an opportunity to layer or reinforce learning from different parts of the course.

20 The self-defence techniques advocated against a 'haymaker' punch, tackle and bear hug 21 in the main are effective, but are out of context. There is no context to the scenario, no 22 verbal exchange and 'ramping up' of the situation before the attack. The subject provides 
a prescribed attack at a comfortable speed and always in a linear fashion from the same

2 direction - head on. (Field notes)

As these officers observed:

4

"Having fun in training is important, but the training needs to have more realism, and examples that we come across in communities."

"It's fine having practical techniques, but you need to learn to use them under stress, and make mistakes in training, not on the street."

“The training just isn't realistic enough, the latest trend out there is MMA (mixed martial arts) fighting, and I'm dealing with people who are better trained than I am."

0 The reality for police officers performing in violent situations, is increased pressure, 1 (physical, cognitive and emotional) (Staller \& Zaiser, 2015), and chaotic circumstances. In contrast to the OST observed and as Jager et al. (2013) suggest, "the attackers don't stand around and attack you stupidly, they charge at you, its chaos" (p. 346).

All of the data sources pointed to a lack of realism in OST that did not deal with the surprising character, aggressiveness and demanding nature of violent situations, an issue that could be addressed with more realistic training. The officers that were interviewed in the present study agreed that if OST were more reality based they would feel less anxious dealing with resistive or violent situations, that their performance in these situations would improve, and they would feel more confident in using force in such situations as this example suggests:

0 "I'd definitely feel more confident in dealing with situations, knowing I'd been through 1 similar examples in training. I' $d$ know that things work under pressure, that I work under 
pressure, make good decisions and be better able to apply force and use the correct

2 techniques" (Officer - interview).

3 Linked to training realism was the low level of engagement with practice with some officers

4 often practicing a technique just once in the allotted time, rather than taking the opportunity to

5 practice.

6 We're in pairs to practice the last technique demonstrated - after one or two repetitions

7 the practice stops and the groups are standing around talking and not doing practice

8 repetitions. After a minute or so the instructor interjects "carry on getting your reps in".

9 Some groups practice the technique just once in that block. (Field notes)

10 This, in the main, was down to the 'blocked' nature of practice, that is, practice one technique

11 at a time in the same way - so if the technique to be practiced was deemed too easy, or the

12 perception from officers was 'they could do it' the likelihood of engagement with the task

13 repetitions was low. Given this relatively low level of engaged activity and the limited amount

14 of repetitions combined with the ecologically weak practice conditions (lack of realism), that

15 research suggests will makes it less likely that police officers will perform in high-pressure

16 situations on duty (c.f. Renden et al., 2015, 2014, Jager et al., 2013). The following data further

17 highlights something of the unrealistic training conditions - cell clearance techniques not in a

18 cell.

19 The far-left corner of the sports hall has two 'padded walls'. Mats are placed on the floor

20 in the corner and this is used to replicate a cell and is used for practicing dealing with an

21 aggressive subject in a cell, cell entry and extraction. However, the practice cell has only

22 two walls and no door or doorframe. Teams of five officers deal with the subject in turn

$23-$ depending on numbers this resulted in up to twenty officers sitting out waiting their 
turn. Today, on this course, the practice cell area is not used, but mats placed on the floor to represent a cell area. All the groups are working, but this 'cell' has no walls or door, so the practice starts with the team already in the 'cell' and the subject on the floor, with

Skill transfer can be fostered in a range of practice activities in the training environment, however a simulation of reality (via scenario based training) is the only viable

7 way of testing the effectiveness of technical skills and tactical solutions to problems encountered in the field (Staller \& Zaiser, 2015) - for police OST this must include surprise

9 attacks (timing and direction), aggressiveness and increasing amounts of pressure (physical, cognitive and emotional) (Jager et al., 2013; Jensen \& Wrisberg, 2014). Practicing using sober, pain-compliant police officers playing the, often passive, role of suspect in the low pressure and controlled environment of the gymnasium, as was the case in the present study, creates a

13 false sense of achievement for officers and instructors (Soderstrom \& Bjork, 2015). Therefore,

14 the evidence in this case suggests that training should be more reality based and sufficiently 15 specific in order to simulate the eventual performance environment and maximise its effects 16 (Murray, 2004; Nieuwenhuys et al., 2009).

\section{Gender Issues}

18 OST is a form of training that is very focused and specific in that it attempts to transmit a series 19 of skills and techniques, however, in addition to its overt curriculum, an informal or 'hidden 20 curriculum' exists in police training which socialises officer's attitudes, values and expectations (Cooper, 2009; Prokos \& Padavic, 2002). Work by Prokos and Padavic (2002)

22 has demonstrated how the hidden curriculum in police training is powerful in constructing and

23 reinforcing notions of masculinity, and can demean and objectify women. The current research 
1 surfaced a particular hidden curriculum that was expressed through and impacted OST, around

2 notions of masculinity and gender. While a distinctive occupational subculture (Waddington,

3 1999) in this case seemed to show OST contributing to an aspect of that subculture promoting

4 masculine values that engendered particular views of women and their role as police officers

5 (Franklin, 2005; Dick \& Jankowicz, 2001). In the present study, female officers were

6 underrepresented on the courses and an informal differentiation occurred during the training

7 that served to demarcate them as 'other' and for some was the basis, of the devaluation of

8 women officers.

9 After listening to the briefing and watching a demonstration the group divides itself to 10 practice. The female officers, as a minority on the course, work together throughout, and 11 are pretty much left to get on with it themselves. (Field notes)

12 The female officers work together without any rotation - and get no practice with anyone 13 other than female officers. On this course, the female officers are referred to as the 'lady's 14 group' - which seemed to be an ongoing joke for some participants "lady's that lunch", 15 "lady's on a tea break" - the constant referral to this group seemed to epitomise some 16 attitudes towards female officers. (Field notes)

17 Course trainers across the three courses did nothing to address this demarcation that served 18 as a vehicle to highlight differences between the sexes on the courses, and importantly such 19 differentiation when left unabated can become the basis for devaluation in hierarchical 20 systems (Reskin, 1988).

21 Women's presence on the course seemed to serve for some as a foil in the construction 22 of boundaries between men and women and was used as a means to elevate men's status 23 (cf. Prokos \& Padavic, 2002) as these data suggest: 
One officer has been particularly aggressive during the drills he is sweating and his

2 demeanour suggests that he appears to be enjoying the physical contact both as a 'subject'

3 and as an officer. The group is paired off to practice defending a rugby tackle/ bear hug.

4 For the first time on the course, the females are paired to practice with males. The

$5 \quad$ aggressive officer has been partnered with a female officer. The pairs are about 5 metres

6 apart, the instructor signals to go. The 'subjects' approach the officers and attempt an

7 attack. The aggressive officer charges the female who does not use the technique to

8 defend against this attack. He tackles her and lifts her up onto his shoulders and starts

9 walking round the gym carrying her - the group explode into laughter, including the

10 instructors. Shouts of "health and safety" along with laughter fill the room. The

11 aggressive officer puts the female officer down. There is no instruction or re-instruction,

12 or demonstration of the correct technique. I'm left wondering how the 'lifted officer'

13 feels about the efficacy of the technique and what messages this moment has sent to her

14 as well as the remainder of the group, not only about the technique but about the

15 capabilities of female officers to deal with violent situations. (Field notes)

16 From the behaviour exhibited throughout the training, it was clear that the aggressive

17 officer in this case wished to elevate his own status and demonstrate hyper-masculinity

18 (Franklin, 2005) to the group through his confrontational and aggressive approach to all the

19 drills. At the same time, these actions, with the instructors unwitting complicity, served to

20 devalue an individual female officer demarcating her as 'other'. Highlighting the physical

21 differences between the sexes in this way produced inequality and reinforced notions that

22 men are superior to females - confirming the masculine nature of the job and that females

23 are unfit for it (Prokos \& Padavic, 2002). For female officers, these issues acted to 
1 exacerbate the issues and limitations of the training, while reifying notions of female

2 weakness and a lack of respect for women's abilities.

The group is practicing cell clearances. The mock cell (padded corner of the gym) is being used. A subject plus five officers are taking part the remainder of the group about 23 officers are sitting on benches organised in an ' $L$ ' shape observing. The cell clearance team consist of one officer for each arm, one for head and torso, and one for legs who is required to be on their knees and 'wrap up' the subject's legs around the knees. The practice begins 'passively', with the subject allowing each officer to take their positions before he resists. The last person to take up position is the leg officer, who is female. Because she has approached from directly in front rather than off to the side (which is to avoid getting kicked), she is now kneeling in front of the subject's groin. At this point, a 2 few calls go out from the observing group, "oh "ello", "Oi, Oi”, then there's laughter 3 from the observing officers. Some are not laughing however, but look to the ground, but 4 they don't say or do anything. The instructor's wait also not saying anything and one 5 eventually walks into the 'cell' and moves the leg officer into the correct position - the 6 laughter continues. (Field notes)

17 At best this type of incident is demeaning, at worst sexual harassment. In training, these 18 types of behaviour contributed to a hidden curriculum that served to disparage female 19 officers through both physical and verbal denigration as well as objectifying them (Prokos $20 \&$ Padavic, 2002). Moreover, the lack of action taken by ranking officers on the course, as 21 well as the course instructors, could send and reinforce the message to all officers that such 22 behaviour is condoned by the institution. The association of violence, masculinity and 23 females in policing is an element of police culture that warrants further investigation - and 
1 certainly the impact of this relationship on the essential element of officer training. Indeed,

2 one female officer commented "not much intimidates me but there's something about these

3 courses (OST) that scares me, which probably isn't the objective of the course". The

4 findings in this case suggest that this relationship further undermines the effectiveness of

5 this training while also doing little to challenge barriers faced by women officers.

6 Lastly, the structuring of the courses meant that women officers, with few exceptions,

7 practiced techniques against each other, being denied the opportunity to practice against

8 bigger, stronger or more experienced subjects - thus, as the data has suggested, appearing

9 less competent (to themselves, colleagues and to the trainers). While individual trainer

10 attention was limited overall, women officers received less and sometimes no individual

11 attention. Given these experiences of training it is perhaps unsurprising that the women

12 officer respondents on the courses felt less confident using OST techniques. These

13 participants reported negative reflections and comments suggesting that they would try to

14 avoid violent situations, and commenting on their use of force being too little or too late: "I

15 should have been better at using these skills", or "I'm just not confident at going in and I

16 end up not using enough force". Interestingly, like data from the male officers interviewed

17 they suggested that more reality-based training would improve their confidence, reduce

18 anxiety and improve their performance in resistive or violent situations.

\section{Conclusions \& Recommendations for Practice}

20 Considering existing training structures

21 Developing training environments that ensure the development of officers competent in the use

22 of force is crucial in police officer training and in meeting an ethical ideal of how police officers

23 use force (Neyroud \& Beckley, 2001; Buttle, 2007). There is support in the literature for more 
1 training (e.g., Buttle, 2007; Renden et al., 2015) and recognition from the interviewed officers

2 in this case of the benefits of this. However, in the current political and economic climate 3 increases in frequency and duration of OST is unlikely. Thus, it is essential that training

4 delivery offers the maximum opportunity that is realistically possible to ensure skill transfer

5 and learning. However, research on the performance of officers in conflict situations supported

6 by comments from training observed and the officers interviewed in this case suggests that

7 training falls short as it is not sufficiently realistic to allow officers to over-ride their stimulus

8 driven reactions and avoidance behaviours (cf. Andersen \& Gustafsberg, 2016). Therefore,

9 given this, and the findings from the present study there is a need to ask if the current training

10 delivery results in officers sufficiently prepared to manage violence during their work. While

11 more practice leads to more automated skill execution (Renden et al., 2015), OST course

12 observations illustrated a number of issues including a lack of realistic training, limited time

13 on task, and poor engagement with tasks during training. Instructors bemoaned the lack of

14 training time "you only get a day and a half a year, some of you just a day", however, the time-

15 on-task data suggests current available training time is not maximised.

The findings from the present study highlight a need to maximise practice time-on-task,

17 which includes reality-based practice under pressure. Training under more threatening or 18 pressured circumstances is effective at inhibiting avoidance behaviour and maintaining goal19 directed behaviour (Renden et al., 2014; Nieuwenhuys \& Oudejans, 2012). Optimal training 20 must include dynamic processes, training the necessary skills in an increasingly stressful and 21 realistic environment; and providing opportunities for increasing one's confidence in his or her 22 ability to perform during stress (cf. Andersen \& Gustafsberg, 2016). However, training under 23 pressure involves increased physical demand, with the interview and observational data in this 24 case suggesting a perception that this would lead to more injuries. As a result, a risk-averse 
1 training culture appears to have evolved that has a focus on 'getting people through' - and as

2 Waddington et al. (2006) suggests such provision "discharges organisational obligations for

3 'due diligence"' (p. 183) without addressing evidence of training effectiveness.

$4 \quad$ An alternative approach - reality-based training

5 In developing more reality-based training one possible route to explore involves the so called

6 'reflex based' or 'flinch response'; instinctive reflexes to protect the body (Cobb \& Pincus, 7 2003; Hulsof \& Spapens, 2014; Renden, Savelsberg \& Oudejans, 2017). Training that teaches

8 officers to convert their primary reflexes into tactical responses and practicing these in 9 representative scenario-based training has been shown to improve police officer performance 10 in high pressure arrest situations (e.g. Cobb \& Pincus, 2003; Hulsof \& Spapens, 2014; Renden 11 et al., 2017). Suggesting that "reflex-based self-defence training better prepares officers for 12 performing in high-pressure arrest situations than the current form of police arrest and self13 defence skills training” (Renden et al., 2017, p. 669) Therefore, rather than append different aspects and techniques to the existing 15 programme 'structure' a revision to a more integrated training could be considered - including dialogic training approaches based on problem solving and representative scenarios repeated

17 under increasing pressure. Officers need to accumulate experience by performing skills under 18 complicated circumstances, as can be suggested from the findings of the present study time 19 and effort are wasted when movements are trained in a simple and 'blocked' way (Soderstrom, 20 \& Bjork, 2015), hence training strategy is an important contributor to performance and 21 learning. Training strategy could also consider taking a more cyclical approach to carrying out, 22 reviewing and evaluating tasks rather than the current model of front-loaded 23 presentation/demonstration by instructors and reproduction and repetition (or not) by officers. 
2 observed, it would suggest a 'way of training' has evolved, based on the instructor's own 3 training and on perceptions of 'what training should look like' and 'what works'. The

4 instructors, as suggested, are time pressed and have limited time for reflection on their own

5 practice and are therefore constrained and limited by what they know. Hence, further research

6 is required that reviews instructor training provision, to fill the gaps for instructors and those

7 responsible for training with the latest developments in the training of ASDS, and more 8 innovative pedagogy for the delivery of such training.

\section{Addressing the 'hidden curriculum}

Lastly, the present study identified some elements of negative police culture, namely

11 evidence of sexism. In this case, these issues exacerbated factors that impacted negatively on

12 training effectiveness for female officers. In the design of OST more critical thought is required 13 about how the course is structured (grouping of officers), and how ASDS is practiced and 14 feedback provided - so female officers have the necessary practice (with male and female 15 subjects) and corrective feedback so to not appear and feel less competent (to themselves, other 16 officers and instructors). It is also important for all participants in OST to consider how their 17 behaviour contributes to a 'hidden curriculum' constructing notions of masculinity and acts to 18 reinforce notions of women officers as different, inferior and objectified.

\section{References}

20 Andersen, J. P., Pitel, M., Weerasinghe, A., \& Papazoglou, K. (2016). Highly Realistic

21 Scenario Based Training Simulates the Psychophysiology of Real World Use of Force

22 Encounters: Implications for Improved Police Officer Performance. Journal of Law

23 Enforcement, 5(4), 1-13. 
1 Andersen, J. P., \& Gustafsberg, H. (2016). A training method to improve police use of force

2 decision making: A randomized controlled trial. Journal of Police Emergency Response, 6(2),

3 https://doi.org/10.1177/2158244016638708

4 Beighton, C. \& Poma, S. (2015). Expanding professional learning: inside/outside police

5 firearms training. Studies in Continuing Education, 37(2) 187-201.

6 Berg, B. L. (2007). Qualitative Research Methods for the Social Sciences. Boston:

7 Pearson Education, Inc.

8 Berliner, D. C. (1979). Tempus educare. In P. L. Peterson, \& H. J. Walberg (Eds.), Research

9 on Teaching: Concepts Findings and Implications, pp. 120-135. Berkely CA:McCutchan.

10 Bernstein, N. A. (1996). On Dexterity and its Development. Mahwah NJ: Lawrence Erlbaum.

11 Braun, V., \& Clarke, V. (2006). Using thematic analysis in psychology. Qualitative Research 12 in Psychology, 3(2), 77-101.

13 Broadbent, D. P., Causer, J., Williams, A. M., \& Ford, P. R. (2015). Perceptual-cognitive skill 14 training and its transfer to expert performance in the field: future research directions. European 15 Journal of Sport Science, 15(4), 322-331.

16 Broome, R. E. (2011). An empathetic psychological perspective of police deadly force training. 17 Journal of Phenomenological Psychology, 42(2), 137-156.

18 Buttle, J. W. (2007). A constructive critique of the officer safety programme used in England 19 and Wales. Policing and Society, 17(2), 164-181.

20 Cobb E., \& Pincus, R. (2003). The SPEAR System ${ }^{\mathrm{TM}}$ and converting the flinch response. $L A W$ 21 AND ORDER - WILMETTE THEN DEERFIELD -, 51(10), 150-159. 
1 College of Policing Limited (2015). Five Year Strategy. Retrieved from

2 http://www.college.police.uk/About/Documents/Five-Year_Strategy.pdf

3 Cooper, F.R. (2009). “Who's the man?”: Masculinities studies, terry stops and police training.

$4 \quad$ Suffolk University Law School Faculty Publications. Paper 57.

5 Denzin, N. K. (1978b). The research act ( $2^{\text {nd }}$ ed). Chicago: Aldine

6 Dick, P., \& Jankowicz, D. (2001). A social constructionist account of police culture and its

7 influence on the representation and progression of female officers. Policing, 24, 181-199.

8 Dror, I. E. (2007). Perception of risk and the decision to use force. Policing, 1(3), 265-272.

9 Ericsson, K. A. (2014). The Road to Excellence: The Acquisition of Expert Performance in 10 Arts and Sciences, Sports, and Games. Mahwah NJ: Lawrence Erlbaum Associates.

11 Franklin, C. A. (2005). Male peer support and the police culture: understanding the resistance 12 and opposition of women in policing. Women and Criminal Justice, 16(3), 1-25.

13 Geller, W. A., \& Toch, H. (1996). Understanding and controlling police abuse of force. In W. 14 A. Geller, \& H. Toch (Eds.). Police Violence Understanding and Controlling Police Abuse of 15 Force. London: Yale University Press.

16 Grünbaum, N. N. (2007). Identification of ambiguity in the case study research typology: what 17 is a unit of analysis? Qualitative Market Research: an International Journal, 10(1), 78-97.

18 Hamstra, S. J., Brydges, R., Hatala, R., Zendejas, B., \& Cook, D. (2014). Reconsidering fidelity 19 in simulation-based training. Academic Medicine, 89(3), 387-392. 
1 Home Office (2017). Statistics on the number of police officers assaulted in 2015/16,

2 England and Wales. Retrieved from,

3 https://www.gov.uk/government/uploads/system/uploads/attachment_data/file/539200/hosb0

4 516-assaults.pdf

5 Hulsof M., \& Spapens, R. (2014). Training arrest and self-defence skills with law enforcement.

6 Unpublished MSc dissertation. Politie VU, University of Amsterdam.

7 Jager, J., Klatt, T., \& Bliesener, T. (2013). NRW-Studie: Gewalt gegen Polizeibeamtinnen und

8 Polizeibeamte. Department of Psychology, Christian-Albrechts-University, Kiel, Germany.

9 Jensen P. R., \& Wrisberg, C. A. (2014). Performance under acute stress: A qualitative study of 10 soldiers' experiences of hand-to-hand combat. International Journal of Stress Management, 11 21(4), 406-423.

12 Kaminski, R. J., \& Martin, J. A. (2000). An analysis of police officer satisfaction with defence 13 and control tactics. Policing: An International Journal of Police Strategy Management, 23(2), $14 \quad 123-153$.

15 Karp, S. \& Stenmark, H. (2011). Learning to be a police officer. Tradition and change in the 16 training and professional lives of police officers. Police Practice and Research: An 17 International Journal 12(1), 4-15.

18 Miller, L. (2007). METTLE: Mental toughness training for law enforcement. New York: 19 Looseleaf Law Publications.

20 Miller, J., \& Alexandrou, B. (2016). College of policing stop and search experiment; Impact 21 evaluation. College of Policing: London. 
1 Morrison, G. B., \& Garner, T. K. (2011). Latitude in deadly force training: progress of

2 problem? Police Practice and Research, 12(4), 341-361.

3 Murray, K. R. (2004). Training at the speed of life, Volume One: The definitive textbook for 4 military and law enforcement reality based training. Gotha, FL: Armiger Publications.

5 Neyroud, P., \& Beckley, A. (2001). Policing, Ethics and Human Rights. Compton, Devon: 6 Willan Publishing.

7 Nieuwenhuys, A., \& Oudejans, R. R. D. (2012). Anxiety and perceptual motor performance:

8 Toward an integrated model of concepts, mechanisms and processes. Psychological Research, $9 \quad 76(6), 747-759$.

10 Patton, M. (1990). Qualitative Researching. London: Sage Publications.

11 Prokos, A., \& Padavic, I. (2002). 'There oughtta be a law against bitches: Masculinity lessons 12 in police academy training. Gender, Work and Organisation, 9(4), 439-459.

13 Renden, P. G., Savelsbergh, G. J. P., \& Oudejans, R. R. D. (2017). Effects of reflex-based 14 self-defence training on police performance in simulated high-pressure arrest situations, 15 Ergonomics, 60(5), 669-679, DOI: 10.1080/00140139.2016.1205222 16

17 Renden, P. G., Landman, A., Geerts, S. F., Jansen, S. E. M., Faber, G. S., Savelsbergh, G. J. 18 P., \& Oudejans, R. R. D. (2014). Effects of anxiety on the execution of police arrest and self19 defence skills. Anxiety, Stress \& Coping, 27(1), 100-112.

20 Renden, P. G., Nieuwenhuys, A., Savelsbergh, G. J. P., \& Oudejans, R. R. D. (2015a). Dutch 21 police officers' preparation and performance of their arrest and self-defence skills: A 22 questionnaire study. Applied Ergonomics, 49, 8-17. 
1 Renden, P. G., Landman, A., Savelsbergh, G. J. P., \& Oudejans, R. R. D. (2015b). Police arrest

2 and self-defence skills: performance under anxiety of officers with and without additional 3 experience of martial arts. Ergonomics, 58(9), 1496-1506.

4 Rosenbaum D.P., \& Lawrence D.S. (2017). Teaching procedural justice and communication 5 skills during police-community encounters: Results of a randomized control trial with police 6 recruits. Journal of Experimental Criminology, 13(3), 293-319.

7

8 Siedentop, D. (2002a). Ecological perspectives in teaching research. Journal of Teachng in $9 \quad$ Physical Education, 21, 427-440.

10 Soderstrom N. C., \& Bjork, R. A. (2015). Learning versus performance: An integrative review. 11 Perspectives on Psychological Science, 10(2), 176-199.

12 Scharf, P., \& Binder, A. (1983). The Badge and the Bullet: Police Use of Deadly Force. New 13 York: Praeger.

14 Staller, M. S., \& Zaiser, B. (2015). Developing problem solvers: New perspectives on 15 pedagogical practices in police use of force training. Journal of Law Enforcement, 4(3), 1-15.

16 Thomas, G. (2011). A typology for the case study in social science following a review of 17 definition, discourse, and structure. Qualitative Enquire, 17(6), 511-521.

18 Timmer, J., \& Pronk, G. (2011). Comparing of police use of violence in the EU. In (Ed). C. 19 Lorei, Eigensicherung und Schusswaffeneinsatz bei der Polizei: Beitrage aus Wissenschaft und 20 Praxis, pp. 181-192. Frankfurt: Verlag vor Polizeiwissenschaft. 
1 van der Mars, H. (2006). Time and learning in physical education. In D. Kirk, D. McDonald,

2 \& M. O'Sullivan (Eds.), The Handbook of Physical Education, pp. 191-213. London:

3 Routledge.

4 Waddington, P.A.J. (1999). Police (canteen) subculture: An appreciation. British Journal of 5 Criminology, 39, 287-309.

6 Waddington, P.A.J., Badger, D., \& Bull, R. (2006). The violent workplace. London: Routledge.

7 Werth, E. (2011). Scenario Training in police academies: developing students' higher-level 8 thinking skills. Police Practice and Research, 12(4), 325- 340.

9 Wheller, L., \& Morris, J. (2010). What works in training and behaviour change and 10 implementing guidance. National Police Improvement Agency (NPIA): Research, Analysis 11 and Information Unit (RAI), UK.

12 Wheller, L, Quinton, P. Fildes, A, Mills, A (2013), The Greater Manchester Police

13 procedural justice training experiment: The impact of communication skills training on 14 officers and victims of crime. College of Policing, UK.

15 Yin, R. K. (2013). Case study research: Design and methods. Sage publications. 